\title{
ANALYSIS OF TOURIST TURNOVER IN A RURAL TOURISM DESTINATION - CASE STUDY OF IVANJICA
}

\author{
Zorica Sagić1, Marija Lakićević2, Danijela Durkalić ${ }^{3}$ \\ *Corresponding author E-mail: danijela.durkalic@kg.ac.rs
}

A R T I C L E I N F O
Review Article
Received: 28 June 2019
Accepted: 28 August 2019
doi:10.5937/ekoPolj1903835S
UDC 338.48-44(1-22)(497.11 Ivanjica)

Keywords:

tourist turnover, rural tourism, Ivanjica, tourism destination, rural areas

JEL:Z13, Z32

\section{A B S T R A C T}

The purpose of the paper is to present a rural tourism destination and its tourist turnover, in the case study of Ivanjica municipality. Rural tourism is one of the leading tourism products in the global tourism market. Rural tourism destinations have become very prominent in many countries, including Serbia. Within these destinations there are various tourism elements such as traditional culture, archaeological and architectural heritage, gastronomy, recreation, history, sports, etc. Rural area is not just a village. Rural areas also refer to all settlements with no city status. The paper presents the statistical analysis results of tourist turnover in Ivanjica municipality from 2011 to 2018 . The statistical analysis is based on data obtained from Tourist Organisation of Ivanjica. Based on analysis results, Discussion and Conclusions provide an overview of the current situation, as well as recommendations for future activities aimed at improving tourist turnover in this destination.

(C) 2019 EA. All rights reserved.

\section{Introduction}

Tourism is an activity which may have a significant influence on the economic, social, functional and physiognomic structure of rural areas. Village tourism is a very broad concept, which includes not only a vacation in the countryside, but also various other tourist activities in rural areas (Todorović, Bjeljac, 2009). Hall and Richards (2005) strongly emphasise the pressure of contradiction that exists between successful tourism development (generally speaking more visitors) and attractiveness of rural regions (in general peace and silence). The international growth of inbound travels has been reflected in positive numbers in the inbound tourism as well (Fodranová et al., 2019).

1 Zorica Sagić, Ph.D., Professor, High School of Vocational Studies Uzice, Sveti Sava Square 34, 31000 Užice, Phone: +381605053003, E-mail: zoricasagic@gmail.com, ORCID ID: https://orcid.org/0000-0003-1124-2542

2 Marija Lakićević, Ph.D., Assistant Professor, University of Kragujevac, Faculty of Hotel Management and Tourism in Vrnjačka Banja, Vojvođanska Street 5A, 36210 Vrnjačka Banja, Phone: +38162609204, E-mail: marija.lakicevic@kg.ac.rs, ORCID ID: https:// orcid.org/0000-0003-2169-7575

3 Danijela Durkalić, Teaching assisstant, University in Kragujevac, Faculty of Hotel Managementand Tourism, Vojvodjanska 5A, 36210 Vrnjačka Banja, Serbia,+381645806599, danijela.durkalic@kg.ac.rs, ORCID ID: https://orcid.org/0000-0001-8605-8614 
Tourism as an activity indicates the overall economic and cultural development and standards of a country. Tourist movements are an integral part of modern civilisation. By their own nature and development possibilities, they have become an important factor of the overall economic development of Serbia (Plavša, Gajić-Ostojić, 2010). Tourism is particularly important for economies in transition with increasing number of unemployed industrial workers looking for their business opportunities in rural areas (Štetić, et al., 2014). Also, tourism industry enhances many economic and noneconomic activities, stimulates underdeveloped regions and increases employment (Čomić, Kosar, 1996). In other words, rural tourism has long been considered a means of achieving economic and social development and regeneration. More specifically, it has been widely promoted as an effective source of income and employment, particularly in peripheral rural areas (Sharpley, 2002).

The Republic of Serbia has no official definition of rural areas. The existing statistical classification of settlements is most often used for defining rural areas. This classification is based on the legal criterion for determining urban settlements, while settlements outside this category are classified as other settlements and thus identified as rural settlements (Gajić, 2015). Depending on the problems and objectives of the research, countries across Europe use different criteria for defining rural and urban areas. The only internationally accepted definition of rural and urban areas is based on the methodology used by the OECD (Organisation for Economic Co-operation and Development), which defines rural areas by population density.

Rural settlements are settlements with population density below 150 inhabitants per $\mathrm{km} 2$ (OECD, 2011). According to this definition, rural areas occupy about $90 \%$ of the territory of the Republic of Serbia, with about $43 \%$ of total population living in these rural areas. Serbia does not have a long tradition in rural tourism. However, the 1970s may be considered as a start of village tourism in Serbia. Although Serbia possesses a diversified structure of attractiveness, this structure is not accompanied by an adequate profile of tourist products (Todorović, Bjeljac, 2009).

As a very important component of tourism development, tourist turnover provides data on tourist movement patterns in a destination (Omerović, 2014). In fact, tourist turnover is an indicator of the total number of tourists and their overnight stays. It's systematic and aggregate indicator, because it includes both above mentioned categories (the total number of tourists and overnight stays). There are three dimensions of tourist turnover: volume, dynamics and structure. The volume refers to a number of tourists and/or a number of their overnight stays. Dynamics as turnover dimension, expresses a change in its volume over a given time period. A tourist turnover structure represents its distribution and is most often shown as a percentage (in relation of the total amount or volume of tourist turnover). In this regard, tourist turnover can be viewed as the volume, dynamics and structure of the total number of tourists i.e., the volume, dynamics and structure of the realised overnight stays (Bakić, et al., 1999). 
Keeping records of tourist turnover is mandatory and regulated in most countries. Turnover of domestic tourists and turnover of foreign tourists are separated. The estimation of the tourist turnover volume is based on the Statistical Office of the Republic of Serbia's official data. The available tourist turnover data are summarized and then divided by the number of reported years. The tourist turnover volume is estimated using the following statistics (Regulation for categorization of tourist sites, 2015):

a number of tourist arrivals;

a number of overnight stays in the accommodation facilities;

a number of overnight stays in the accommodation facilities during a year compared to resident population.

Regarding tourism demand forecasting, there are numerous models for forecasting foreign tourist arrivals. Over the past three decades, SARIMA (Seasonal Autoregressive Integrated Moving Average Model) is one of the most popular time series model in the field of tourism demand forecasting. In addition, Grey model has been successfully applied in tourist arrivals forecasting (Chandra, Kumari, 2018).

As a typical rural tourism area, Ivanjica is very attractive especially for tourists coming from large industrial urbanized zones and lowland areas. Ivanjica municipality fosters all forms of tourism, ranging from health tourism to rural tourism.

\section{Rural tourism in Ivanjica municipality}

Ivanjica is a small town and municipality located in Moravica District of south-western Serbia. Ivanjica is the administrative, economic and cultural centre of this region. It is $224 \mathrm{~km}$ away from Belgrade. The current population of the municipality is 32,385 . Its geographical position and the fact that it is surrounded by the mountain ranges of Golija, Javor, Mučanj, Čemerno i Radočelo, make Ivanjica an exceptional destination for rural tourism development. Because Ivanjica municipality is very rich in natural wealth, huge forest resources, numerous water sources and has a good road infrastructure, it's extremely interesting area for developing all tourism forms.

Ivanjica is rich in natural attractions such as mountains, rivers and lakes. An interesting example is young and still unexplored lake called Nebeska suza (Heaven's Teardrop). The lake was formed after a huge earthquake in Romania in 1977. It has the largest area of all the lakes in Ivanjica municipality (Ostojić, Marković, 2015). The Government of the Republic of Serbia proclaimed Ivanjica to be the first air spa in Serbia in 2000. The United Nations Educational, Scientific and Cultural Organisation (UNESCO) declared Golija Mountain the First category Park of Nature and the Biosphere Reserve in 2001. $70 \%$ of Golija Mountain is located at the territory of Ivanjica municipality (Ćurčić, 2001). All these facts emphasise the natural potential of Ivanjica and are excellent prerequisites for rural tourism investment and development. 
The tourism market is very dynamic and is subject to numerous and frequent changes. The specific tourism market (such as rural tourism) requires specific tourism marketing strategies. Business goals achievement at a tourist destination depends on its ability to satisfy needs of consumers using the optimal combination of marketing instruments and strategic alternatives.

In the literature there are different interpretations of the concept of rural tourism and its manifest forms, determined by the characteristics of the rural area and the availability of resources for the development of rural tourism. For the hosts it is a commercial activity which opens the doors of their homes for guests to enjoy in recreational activities in predominantly rural areas. A wide range of activities that constitute rural tourism product indicates that this form of tourism has no precisely defined target group of tourists (Milićević, et al., 2015).

Ivanjica has significant tourist values. Valorised in unity with natural sights, they make a huge tourism potential. By their appearance, anthropogenic tourist values can be classified as follows:

$$
\begin{aligned}
& \text { - archaeological } \\
& \text { - } \text { monumental } \\
& \text { - } \text { ethnographic } \\
& \text { - } \text { ambient } \\
& \text { - manifestation. }
\end{aligned}
$$

Ivanjica was declared a tourist destination at the beginning of the third decade of the 20th century. Some of the main accommodation facilities in Ivanjica are: Park Hotel (built in 1976, categorised with 4 stars and equipped with 140 beds in single-bed and double-bed rooms as well as 3 apartments and many other modern facilities), Moravica Hotel, Vacation centre Golija (126 beds), etc. In villages near Ivanjica, there are hotels: Golijska Reka in the heart of Golija, Dubrava in Prilički Kiseljak and Javor in Kušići. Happy guests show a larger degree of satisfaction and loyalty and they visit the hotel again, recommend it to their friends, that affects the hotel's profits, and development of tourism as a whole (Vujić, et.al, 2019, p.61). Also, there are several hotels and motels with smaller capacities, such as Mona Hotel in Kušići (on the slopes of Javor), Logos Hotel in Katići (on the slopes of Mučanj), Opaljenik (Javor) and Kapija in Međurečje. In addition, there are many country households and several ethno villages.

Special rehabilitation centre was opened in 1948 and modernised in the 1980s. It represents a combination of health and tourist facilities and has 270 beds in single-bed, double-bed and three-bed rooms, two apartments and accompanying modern facilities (Ostojić, 2011). The oldest tourist destination in Ivanjica municipality is certainly Prilički Kiseljak. It is a spa with average altitude of nearly 500 m (Ostojić, Marković, 2011). There are numerous cultural events in Ivanjica, such as the Nušićijada festival. Nušićijada is an annual comedy festival named after Branislav Nušić, a famous Serbian 
comedy playwright. This cultural event gathers nearly 50,000 visitors every year (www. ivatourism.co.rs).

As the main tourism destination in this region, Ivanjica realises more than 100,000 overnight stays annually, with an average length of stay of five days per guest. Most of the visitors are domestic guests. The season lasts from May to October, and in January (because of winter school holidays), with the season peaks in July and August. Over the past five years, Ivanjica has recorded a very dynamic growth of tourist turnover, after a long period of stagnation (resulting from the general social and political instability) (Marković, et al., 2005).

\section{The research methodology}

\section{The research questions}

The main goal of this research is to explore tourist turnover in Ivanjica municipality. The research questions are as follows:

1) Is Ivanjica being more visited by domestic or by foreign tourists?

2) Do domestic and foreign tourists both realise the same number of overnight stays?

3) Has the number of domestic tourists visits changed over time?

4) Has the number of foreign tourists visits changed over time?

5) Has the domestic tourists' length of stay changed over time?

6) Has the foreign tourists' length of stay changed over time?

7) Has the accommodation capacity changed over time?

8) Has the total length of stay changed over time?

9) Has the total number of tourist visits changed over time?

The research included 4 hotels, a mountain lodge, a rehabilitation centre, a resort and all private accommodation facilities. The sample was the same during the observed time period, i.e., the observed tourist facilities didn't change.

\section{Data Analysis}

Data analysis was performed using secondary data from Tourist Organisation of Ivanjica. The analysis considered tourist turnover in Ivanjica municipality from 2011 to 2018. The Independent Samples t Test was used to determine differences between the number of foreign guests and the number of domestic ones. The t test also was used to determine differences between the number of foreign tourists' overnights and the number of domestic tourists' overnights.

Analysis of variance (ANOVA) with repeated measures was performed (with Greenhouse-Geisser correction because the assumption of sphericity was violated) to 
determine: differences in the number of domestic tourists in the observed time period; differences in the number of foreign tourists in the observed time period; differences in the number of domestic tourists' overnights in the observed time period; differences in the number of foreign tourists' overnights in the observed time period; differences in the number of beds in the observed time period; differences in the number of overnight stays in the observed time period; and differences in the total number of tourists in the observed time period.

\section{Results and Discussion}

Table 1. Descriptive statistics

\begin{tabular}{|c|c|c|c|c|c|c|c|c|}
\hline Year & & $\mathbf{N}$ & Mean & Median & Mode & Standard Deviation & Min & Max \\
\hline \multirow{9}{*}{$\overline{\bar{\nu}}$} & Number of rooms & 8 & 53 & 48,5 & 26 & 31,924 & 18 & 108 \\
\hline & Number of apartments & 5 & 5,2 & 5 & 2 & 3,421 & 2 & 10 \\
\hline & Number of beds & 8 & 133,75 & 117 & 94 & 74,308 & 42 & 270 \\
\hline & Number of domestic tourists & 6 & 2526,33 & 1776 & 249 & 2579,928 & 249 & 6940 \\
\hline & Number of foreign tourists & 5 & 279,8 & 88 & 30 & 361,334 & 30 & 880 \\
\hline & Number of overnight stays of domestic tourists & 6 & 15625,3 & 5942 & 1007 & 25296,012 & 1007 & 66350 \\
\hline & Number of overnight stays of foreign tourists & 5 & 728,6 & 176 & 65 & 1036,201 & 65 & 2524 \\
\hline & Total number of tourists & 6 & 2759,5 & 1976,5 & 279 & 2690,962 & 279 & 7028 \\
\hline & Total number of overnight stays & 6 & 16232,5 & 7564 & 1072 & 25177,437 & 1072 & 66526 \\
\hline \multirow{9}{*}{$\frac{\sim}{\stackrel{\sim}{\sim}}$} & Number of rooms & 8 & 48,38 & 33 & 6 & 38,037 & 6 & 108 \\
\hline & Number of apartments & 4 & 5 & 2,5 & 2 & 5,354 & 2 & 13 \\
\hline & Number of beds & 8 & 131,88 & 107 & 94 & 79,319 & 42 & 270 \\
\hline & Number of domestic tourists & 6 & 2505,17 & 2121 & 240 & 2289,532 & 240 & 6085 \\
\hline & Number of foreign tourists & 5 & 195,6 & 103 & 20 & 261,459 & 20 & 659 \\
\hline & Number of overnight stays of domestic tourists & 6 & 15457,5 & 4327 & 750 & 22413,932 & 750 & 57680 \\
\hline & Number of overnight stays of foreign tourists & 5 & 399,8 & 149 & 30 & 557,711 & 30 & 1376 \\
\hline & Total number of tourists & 6 & 2668,17 & 2505 & 260 & 2359,056 & 260 & 6188 \\
\hline & Total number of overnight stays & 6 & 15790,7 & 5015 & 780 & 22348,43 & 780 & 57783 \\
\hline
\end{tabular}


Economics of Agriculture, Year 66, No. 3, 2019, (pp. 835-850), Belgrade

\begin{tabular}{|c|c|c|c|c|c|c|c|c|}
\hline Year & & $\mathbf{N}$ & Mean & Median & Mode & Standard Deviation & Min & Max \\
\hline \multirow{9}{*}{$\stackrel{m}{\stackrel{n}{n}}$} & Number of rooms & 8 & 37,75 & 27,5 & 18 & 33,005 & 6 & 108 \\
\hline & Number of apartments & 5 & 18 & 3 & 2 & 29,436 & 2 & 70 \\
\hline & Number of beds & 8 & 132 & 110 & 50 & 84,801 & 50 & 270 \\
\hline & Number of domestic tourists & 6 & 2534,5 & 2080,5 & 156 & 2714,937 & 156 & 7145 \\
\hline & Number of foreign tourists & 5 & 184,4 & 65 & 11 & 324,021 & 11 & 762 \\
\hline & Number of overnight stays of domestic tourists & 6 & 15025,8 & 4311 & 277 & 23423,906 & 277 & 60660 \\
\hline & Number of overnight stays of foreign tourists & 5 & 488,6 & 203 & 11 & 764,024 & 11 & 1842 \\
\hline & Total number of tourists & 6 & 2688,17 & 2198,5 & 167 & 2778,212 & 167 & 7160 \\
\hline & Total number of overnight stays & 6 & 15433 & 5333,5 & 288 & 23329,527 & 288 & 60755 \\
\hline \multirow{9}{*}{$\underset{\sim}{\stackrel{\Delta}{S}}$} & Number of rooms & 8 & 37,75 & 27,5 & 18 & 33,005 & 6 & 108 \\
\hline & Number of apartments & 5 & 18,2 & 3 & 2 & 29,878 & 2 & 71 \\
\hline & Number of beds & 8 & 132,5 & 110 & 50 & 85,57 & 50 & 270 \\
\hline & Number of domestic tourists & 6 & 2161,83 & 1650,5 & 108 & 2296,05 & 108 & 5949 \\
\hline & Number of foreign tourists & 5 & 177 & 56 & 4 & 289,778 & 4 & 689 \\
\hline & Number of overnight stays of domestic tourists & 6 & 12663,3 & 2877 & 191 & 20377,908 & 191 & 51981 \\
\hline & Number of overnight stays of foreign tourists & 5 & 466,2 & 183 & 16 & 727,5 & 16 & 1760 \\
\hline & Total number of tourists & 5 & 2749,6 & 3148 & 120 & 2305,064 & 120 & 5965 \\
\hline & Total number of overnight stays & 6 & 13051,8 & 3848,5 & 207 & 20292,331 & 207 & 52127 \\
\hline \multirow{9}{*}{$\frac{n}{\stackrel{n}{d}}$} & Number of rooms & 8 & 37,75 & 27,5 & 18 & 33,005 & 6 & 108 \\
\hline & Number of apartments & 5 & 18,2 & 3 & 2 & 29,878 & 2 & 71 \\
\hline & Number of beds & 8 & 132,5 & 110 & 50 & 85,57 & 50 & 270 \\
\hline & Number of domestic tourists & 5 & 2318,4 & 1085 & 41 & 2685,774 & 41 & 6183 \\
\hline & Number of foreign tourists & 4 & 109,5 & 60,5 & 15 & 132,475 & 15 & 302 \\
\hline & Number of overnight stays of domestic tourists & 5 & 16280,6 & 1737 & 187 & 24415,522 & 187 & 56753 \\
\hline & Number of overnight stays of foreign tourists & 4 & 271,25 & 104,5 & 71 & 356,354 & 71 & 805 \\
\hline & Total number of tourists & 5 & 2406 & 1387 & 41 & 2688,631 & 41 & 6274 \\
\hline & Total number of overnight stays & 5 & 16497,6 & 2542 & 187 & 24331,077 & 187 & 56844 \\
\hline \multirow{9}{*}{$\stackrel{\circ}{\stackrel{\sim}{\sim}}$} & Number of rooms & 6 & 62,17 & 49,5 & 32 & 41,878 & 18 & 114 \\
\hline & Number of apartments & 0 & & & & & & \\
\hline & Number of beds & 6 & 156,67 & 125 & 42 & 97,508 & 42 & 279 \\
\hline & Number of domestic tourists & 5 & 3477,8 & 3789 & 210 & 3328,542 & 210 & 8063 \\
\hline & Number of foreign tourists & 4 & 275,25 & 32 & 2 & 507,213 & 2 & 1035 \\
\hline & Number of overnight stays of domestic tourists & 5 & 18655,8 & 9046 & 735 & 25150,27 & 735 & 60996 \\
\hline & Number of overnight stays of foreign tourists & 4 & 628,75 & 116 & 2 & 1104,941 & 2 & 2281 \\
\hline & Total number of tourists & 5 & 3698 & 3849 & 210 & 3478,161 & 210 & 8065 \\
\hline & Total number of overnight stays & 5 & 19158,8 & 11327 & 735 & 24952,429 & 735 & 60998 \\
\hline
\end{tabular}


Economics of Agriculture, Year 66, No. 3, 2019, (pp. 835-850), Belgrade

\begin{tabular}{|c|c|c|c|c|c|c|c|c|}
\hline Year & & $\mathbf{N}$ & Mean & Median & Mode & Standard Deviation & Min & Max \\
\hline \multirow{9}{*}{$\stackrel{\sqrt{\circ}}{\circ}$} & Number of rooms & 6 & 61,83 & 48 & 18 & 42,823 & 18 & 114 \\
\hline & Number of apartments & 0 & & & & & & \\
\hline & Number of beds & 6 & 151,17 & 112 & 42 & 97,008 & 42 & 291 \\
\hline & Number of domestic tourists & 6 & 3325,17 & 2510 & 109 & 3433,496 & 109 & 7966 \\
\hline & Number of foreign tourists & 5 & 185 & 25 & 3 & 329,84 & 3 & 770 \\
\hline & Number of overnight stays of domestic tourists & 6 & 16544,7 & 8059 & 492 & 22344,158 & 492 & 57888 \\
\hline & Number of overnight stays of foreign tourists & 5 & 389,8 & 68 & 6 & 701,106 & 6 & 1634 \\
\hline & Total number of tourists & 6 & 3479,33 & 2578,5 & 109 & 3591,441 & 109 & 7981 \\
\hline & Total number of overnight stays & 6 & 16869,5 & 8879 & 492 & 22336,868 & 492 & 57903 \\
\hline \multirow{9}{*}{$\stackrel{\infty}{\stackrel{\sim}{\sim}}$} & Number of rooms & 6 & 61,17 & 48 & 18 & 42,654 & 18 & 114 \\
\hline & Number of apartments & 0 & & & & & & \\
\hline & Number of beds & 6 & 149,67 & 125 & 42 & 91,577 & 42 & 268 \\
\hline & Number of domestic tourists & 5 & 3452,8 & 4268 & 177 & 3111,89 & 177 & 7129 \\
\hline & Number of foreign tourists & 3 & 338,67 & 49 & 2 & 542,929 & 2 & 965 \\
\hline & Number of overnight stays of domestic tourists & 5 & 19052,4 & 10781 & 1048 & 24046,546 & 1048 & 58970 \\
\hline & Number of overnight stays of foreign tourists & 3 & 792,33 & 736 & 4 & 817,956 & 4 & 1637 \\
\hline & Total number of tourists & 5 & 3656 & 4317 & 179 & 3289,882 & 179 & 7129 \\
\hline & Total number of overnight stays & 5 & 19527,8 & 12418 & 1052 & 23946,246 & 1052 & 58970 \\
\hline \multirow{9}{*}{ 芯 } & Number of rooms & 58 & 48,76 & 32 & 18 & 35,849 & 6 & 114 \\
\hline & Number of apartments & 24 & 13,25 & 3 & 2 & 22,549 & 2 & 71 \\
\hline & Number of beds & 58 & 138,72 & 112 & 100 & 81,348 & 42 & 291 \\
\hline & Number of domestic tourists & 45 & 2768,07 & 2333 & 41 & 2631,054 & 41 & 8063 \\
\hline & Number of foreign tourists & 36 & 212,89 & 62,5 & 15 & 318,243 & 2 & 1035 \\
\hline & Number of overnight stays of domestic tourists & 45 & 16041 & 4447 & 187 & 21539,591 & 187 & 66350 \\
\hline & Number of overnight stays of foreign tourists & 36 & 509,5 & 167 & 226 & 722,026 & 2 & 2524 \\
\hline & Total number of tourists & 44 & 3002,7 & 2761,5 & 41 & 2722,018 & 41 & 8065 \\
\hline & Total number of overnight stays & 45 & 16448,6 & 6207 & 187 & 21456,816 & 187 & 66526 \\
\hline
\end{tabular}

Source: Authors' calculations 
Figure 1. The number of tourists in the observed time period

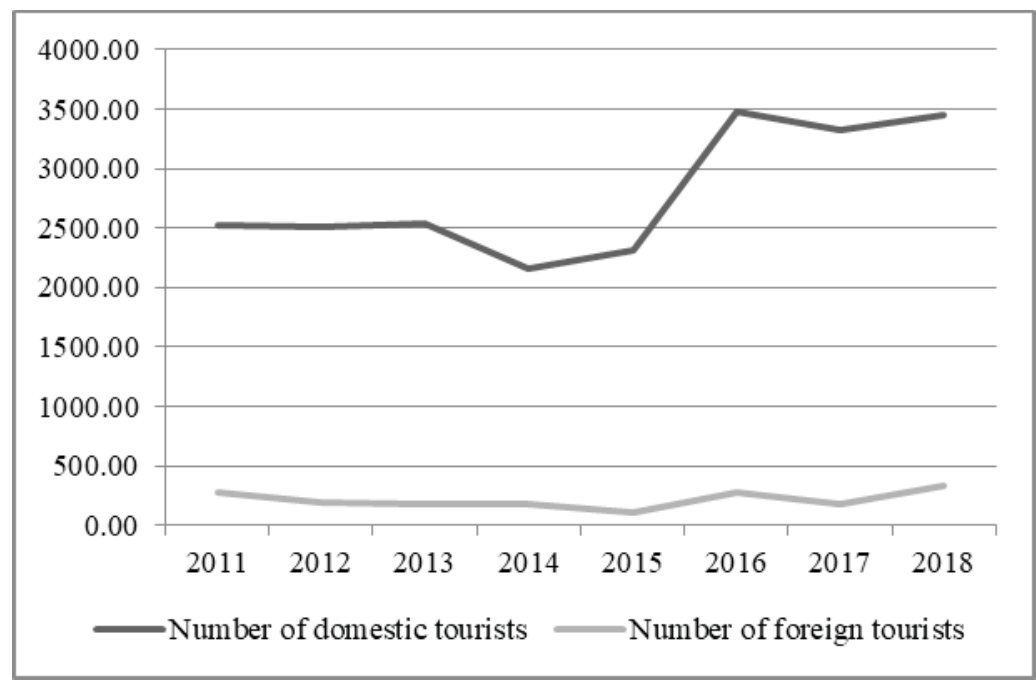

Source: Authors' calculations

It can be noted that on average Ivanjica was visited more by domestic tourists (124563) than by foreign tourists (7664). On average, the number of domestic tourists ( $M=2768.07)$ grew at a rate of $4.56 \%$ per year, while the number of foreign tourists $(M=212.89)$ grew at an average annual rate of $2.76 \%$. It can be noted (Figure 1.) that in 2005, there was a large increase in the number of domestic tourists. In the observed time period Ivanjica municipality was significantly more visited by domestic tourists $(\mathrm{M}=2768.07$; $\mathrm{SD}=2631.05)$ than by foreign tourists $(\mathrm{M}=212.89 ; \mathrm{SD}=318.24) ; \mathrm{t}(46)=6.46 ; \mathrm{p}=0.00$. The results indicate that this area must be focused on attracting more foreign tourists. Ivanjica municipality has a potential to do so, but it is important for tourism officials to better understand the needs of potential foreign visitors and to design appropriate tourism marketing strategies.

There were no significant differences in the number of domestic tourists in Ivanjica municipality in the observed time period, $F(1.02)=2.82 ; p=0.17$; partial $\eta^{2}=0.41$. It was also found that there were no significant differences in the number of foreign tourists in Ivanjica municipality in the observed time period, $F(1)=1.09 ; p=0.49$; partial $\eta^{2}=0.52$. 
Figure 2. The number of overnight stays in the observed time period

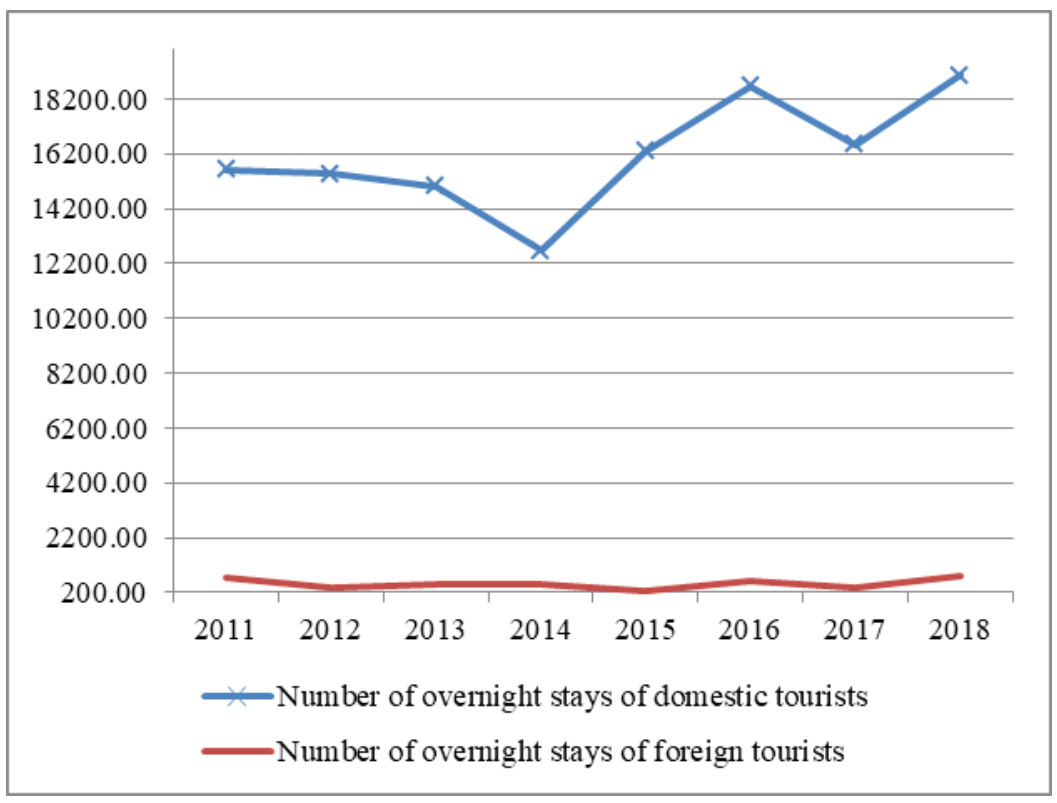

Source: Authors' calculations

The Figure 2. shows that domestic tourists realised more overnights on average (721844) than foreign tourists (18342). On average, the number of overnight stays of domestic tourists $(\mathrm{M}=16040.98)$ grew at a rate of $2.87 \%$ annually, while the number of overnight stays of foreign tourists (509.50) grew at an average annual rate of $1.21 \%$. There was a huge increase in the number of domestic tourists in 2015 in Ivanjica. Fewer visits of foreign tourists resulted in fewer overnights of those tourists compared to domestic ones. The strategy for improving poor statistics must be aimed at better identifying needs of existing and potential foreign tourists.

In Ivanjica, domestic tourists realised much more overnight stays $(\mathrm{M}=16040.98$; $\mathrm{SD}=21539.59)$ than foreign tourists $(\mathrm{M}=509.50 ; \mathrm{SD}=722.03) ; \mathrm{t}(44)=4.83 ; \mathrm{p}=0.00$. There were no significant differences in the number of overnight stays of domestic tourists in the observed period, $\mathrm{F}(2.06)=1.30 ; \mathrm{p}=0.32$; partial $\eta^{2}=0.24$. There were also no significant differences in the number of foreign tourists in the observed period, $\mathrm{F}$ (1) $=0.91 ; p=0.51 ;$ partial $\eta^{2}=0.48$. 
Figure 3. The number of overnight stays compared to the number of beds in the observed time period
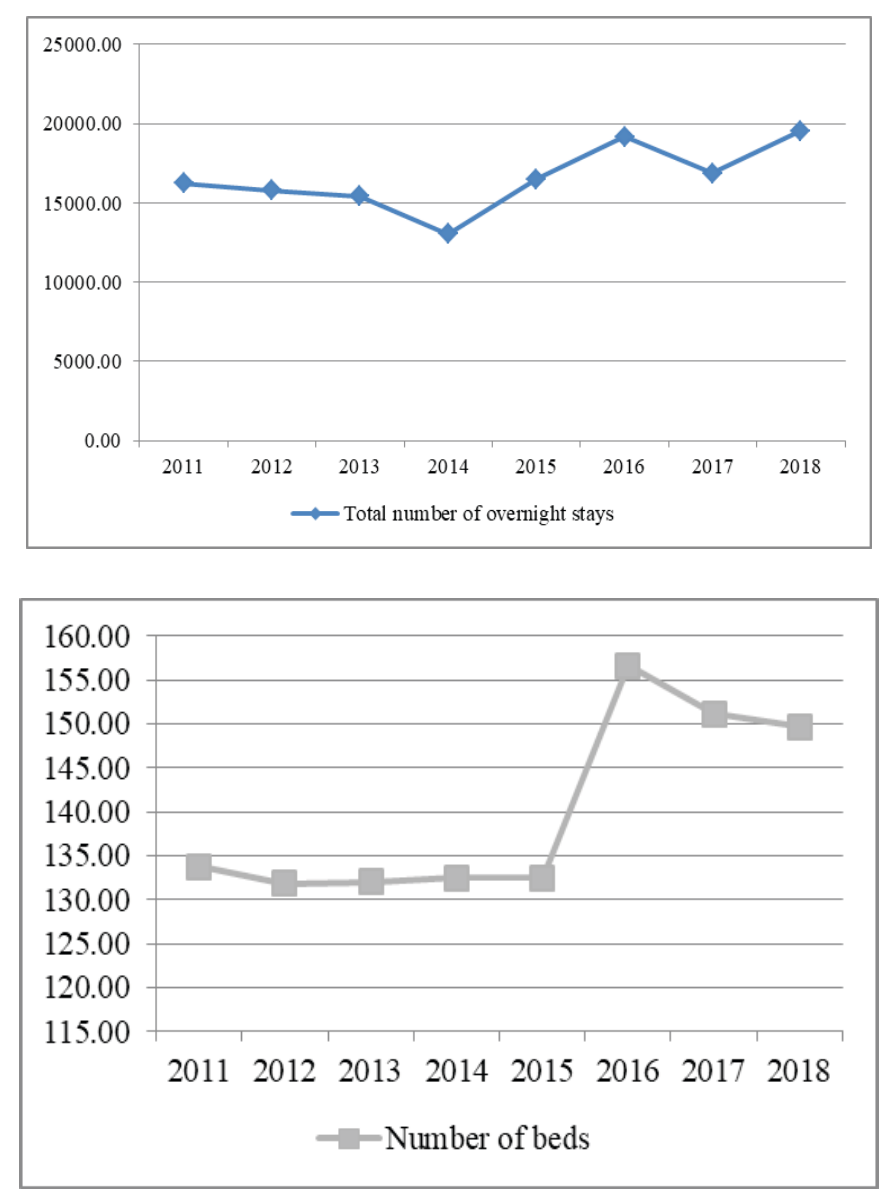

Source: Authors' calculations

The figure 3. shows that in 2014 there was a decline in the total number of overnight stays and in the following year it increased and reached its peak in 2018. On average, the number of beds grew at a rate of $1.62 \%$ annually, while the number of overnight stays grew at an average annual rate of $2.68 \%$. There were no significant differences in the number of beds in the observed period, $\mathrm{F}(1.50)=1.14 ; \mathrm{p}=0.35$; partial $\eta^{2}=0.19$. There were also no significant differences in the number of overnight stays in the observed period, $F(2.07)=1.23 ; \mathrm{p}=0.33$; partial $\eta^{2}=0.24$. 
Figure 4. The number of tourists compared to the number of beds in the observed time period
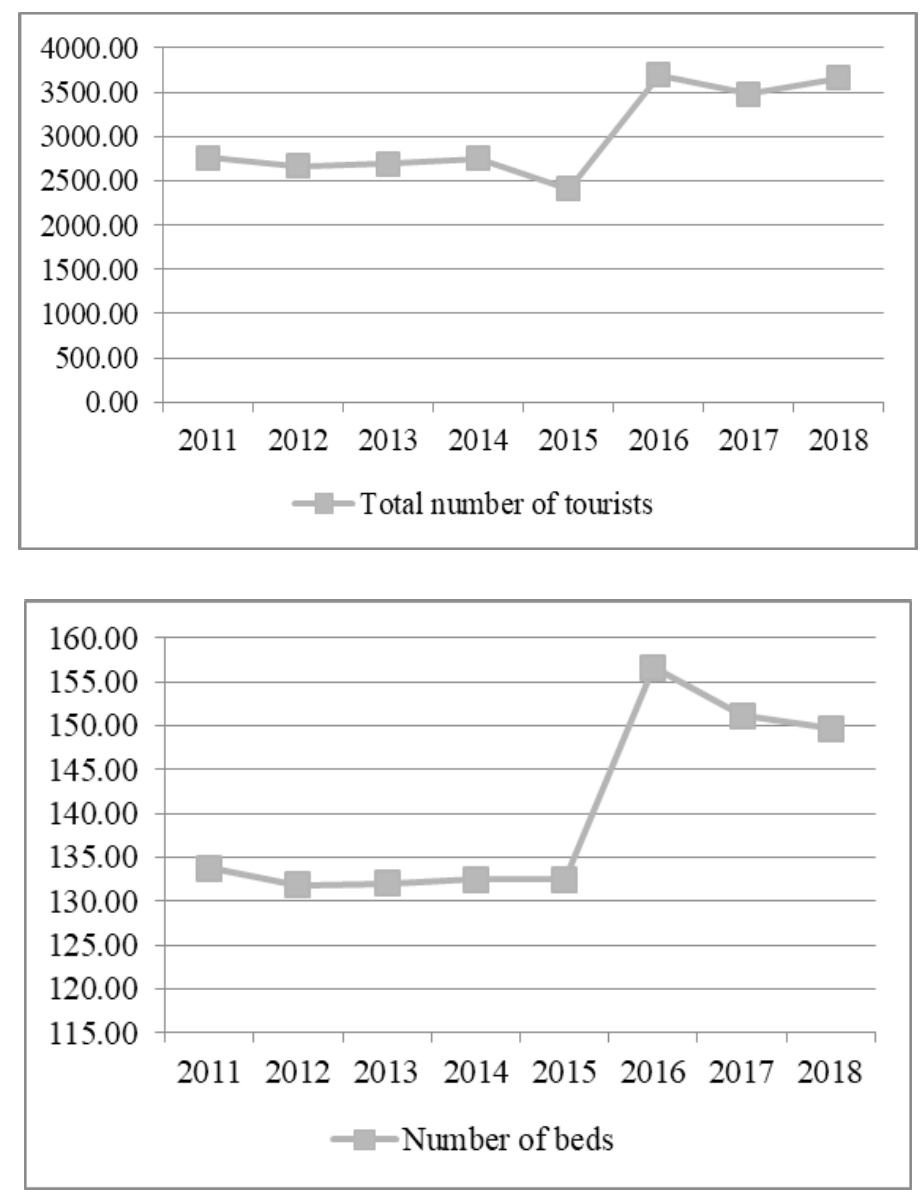

Source: Authors' calculations

The figure 4. shows that there was a significant increase in the number of tourists in 2016. On average, the number of beds grew at a rate of $1.62 \%$ annually, while the number guests grew at an average annual rate of $4.10 \%$. There were no significant differences in the number of tourists in the observed period, $F(1.33)=2.31 ; p=0.21$; partial $\eta^{2}=0.43$. 
Figure 5. The number of tourists compared to the number of overnight stays in the observed time period

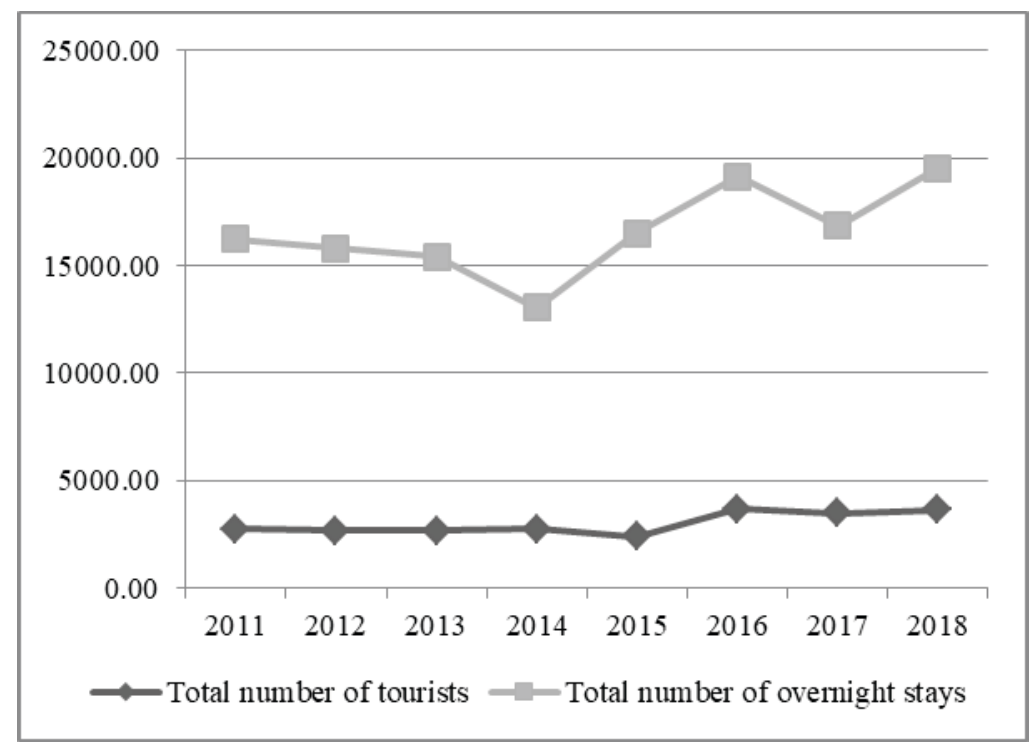

Source: Authors' calculations

The figure 5. shows that in 2014 there was a decline in the total number of overnight stays and in the following year it increased and reached its peak in 2018. On average, the number of tourists grew at a rate of $4.10 \%$ per year, while the number of overnight stays grew at an average annual rate of $2.68 \%$. There was a significant increase in the number of overnight stays in 2016.

\section{Conclusions}

In the past Ivanjica was not an attractive tourism destination. It was just a small Serbian town. But today Ivanjica is something completely different. Especially over the past five years Ivanjica has recorded a very dynamic growth of rural tourism offer and tourist turnover. As a typical rural tourism destination, Ivanjica municipality has very attractive attributes especially for tourists coming from large industrial urbanised areas and lowlands and looking for a peace and a beautiful nature. Various tourism forms are possible in Ivanjica municipality, but rural tourism is a dominant one.

But the tourism potential of this area is not completely exploited. This should be a great challenge and inspiration in the future. Ivanjica municipality and its tourist organisation have to use all available resources in order to improve and promote rural tourism. The emphasis should be on a sustainable rural tourism. The long-term development strategy requires the institutional issues to be solved in a timely manner. A rural tourism management has to take into account economic and environmental sustainability of Ivanjica municipality. 
In terms of tourist turnover structure, domestic tourists are dominant. But Ivanjica has a potential to attract more foreign guests, considering that investments in Golija for developing winter tourism are expected. It should not be forgotten that Ivanjica was declared an air spa, and therefore it is interesting as a destination with healthy food and clean air. For further development of rural tourism it is necessary to include the richness of biodiversity and ecosystems in the tourism offer. The whole world is increasingly turning to so-called eco-destinations. This is a great opportunity for Ivanjica, because it is rich in exceptional natural resources. So far, rural tourism development in Ivanjica municipality has not jeopardised the resources on which it is based, so they remain preserved for the generations to come.

\section{Acknowledgements}

Paper is a part of research within the project no. III 46006 - Sustainable agriculture and rural development in the function of accomplishing strategic objectives of the Republic of Serbia in the Danube region, financed by the Ministry of Education, Science and Technological Development of the Republic of Serbia. Project period: 2011-2019.

\section{Conflict of interests}

The authors declare no conflict of interest.

\section{References}

1. Bakić, O., Nikolić, M., \& Bakić, M. (1999). Osnove turizma sa osnovama ugostiteljstva, Čigoja, Beograd [In English: Bakic, O., Nikolic, M., and Bakic, M. (1999). Basics of tourism with the basics of catering, Čigoja, Belgrade].

2. Chandra, S., \& Kumari, K. (2018). Forecasting foreign tourist arrivals in India using time series models, International Journal of Statistics and Applied Mathematics, 3(2), 338-342.

3. Čomić, Đ., \& Kosar, Lj. (1996). Turizam u procesima globalizacije, Turizam, Novi Sad. [In English: Comić, Đ., \& Kosar, Lj. (1996). Tourism in the Processes of Globalization, Tourism, Novi Sad].

4. Đurčić, U. (2001). Moravički kraj, Turističko - poslovni vodič, Imanuel, Ivanjica. [In English: Đurčić, U. (2001). Moravian Region, Tourist and Business Guide, Imanuel, Ivanjica.].

5. Fodranová, I., Puškelová, M., Mrkvová, K., \& Dudić, B. (2019). Incoming tour operators perspectives in a highly competitive environment-case of Slovakia. Hotel and Tourism Management, 7(1), 25-36.

6. Gajić, A. (2015). Different methodological approaches in defining rural and urban areas, Arhitektura i urbanizam, 41, 63-67. doi.10.5937/a-u0-9506, .

7. Hall, D., \& Richards, G. (2002). Tourism and sustainable community development. London. 
8. Leech, N., Barrett, K., \&Morgan, G. (2005). SPSS for Intermediate Statistics: Use and Interpretation. Second Edition. New Jersey:Lawrence erlbaum associates, publishers.

9. Marković, S., Popović, I., \& Ostojić, M. (2005). Seoski turizam-mogući pokretač razvoja brdskog - planinskog područja Moravičkog kraja, Novi Sad. . [In English: Markovic, S., Popovic, I., \& Ostojic, M. (2005). Rural tourism - a possible driver for the development of mountainous area of Moravica region, Novi Sad].

10. Milićević, S., Podovac, M., \& Čavlin, M. (2015). Resources for development of the Rača Municipality as a rural tourism destination. Economics of Agriculture, 62(3), 751-765.

11. OECD Regional Typology. (2011). Directorate for Public Governance and Territorial Development. Retrieved from: https:/www.oecd.org/cfe/regionalpolicy/OECD_regional_typology_Nov2012.pdf (May 20,2019).

12. Omerović, J. (2014). Turistički promet kao nezaobilazna komponenta razvoja turizma Tuzle, Zbornik radova Departmana za geografiju, turizam i hotelijerstvo, Novi Sad, 43 (2) 174-184. . [In English: Omerovic, J. (2014). Tourism traffic as an indispensable component of Tuzla tourism development, Proceedings of the Department of Geography, Tourism and Hotel Management, Novi Sad, 43 (2), 174184 ].

13. Ostojić, M., \& Marković, S.(2015). Golijska jezera, Turistička organizacija opštine Ivanjica, Čačak. . [In English: Ostojic, M., \& Markovic, S. (2015). Golija Lakes, Ivanjica Tourist Organization, Čačak ].

14. Ostojić, M., \& Marković, S. (2011). Turistički vodič, Turistička organizacija opštine Ivanjica, Čačak. . [In English: Ostojic, M., \& Markovic, S. (2011). Tourist guide, Ivanjica Tourist Organization, Čačak].

15. Ostojić, M. (2011). Ivanjica - turizam na selu, Turistička organizacija opštine Ivanjica, Čačak. . [In English: Ostojic, M. (2011). Ivanjica-rural tourism, Ivanjica Municipality Tourism Organization, Cacak].

16. Plavša, J., \& Gajić-Ostojić, T. (2010). Karakteristike opšte turističke vrednosti i značaja Južnobanačkog okruga kao turističke zone u okviru Srbije, Zbornik radova Departmana za geografiju, turizam i hotelijerstvo, Novi Sad, 39, 92-106., . [In English: Plavša, J., \& Gajić-Ostojić, T. (2010). Characteristics of the general tourist value and importance of the South Banak District as a tourist zone within Serbia, Proceedings of the Department of Geography, Tourism and Hotel Management, Novi Sad, 39, 92-106 ].

17. Rules on the categorization of tourist sites (2015). Official Gazette of the Republic of Serbia, Nos. 24/2012, 31/2012 and iss.102 / 2015, Retrieved from: http://mtt.gov.rs/download/PRAVILNIK\%200\%20KATEGORIZACIJI\%20 TURISTI\%C4\%8CKIH\%20MESTA.pdf (May 18, 2019)

18. Štetić, S., Cvijanović, D., \& Šimićević, D. (2014). Posebni oblici turizma Dunavskog regiona Srbije, Institut za ekonomiku poljoprivrede, Beograd. . [In English: Štetić, S., Cvijanović, D., \& Šmićević, D. (2014). Special forms of tourism of the Danube Region of Serbia, Institute for Agricultural Economics, Belgrade]. 
19. Sharpley, R. (2002). Rural tourism and the challenge of tourism diversification: the case of Cyprus, Tourism Management, 23 (3), 233-244/doi.org/10.1016/S02615177(01)00078-4

20. Sheskin, D. (2004). Handbook of Parametric and Nonparametric Statistical Procedures, $3^{\text {rd }}$ edition. United States of America: Library of Congres.

21. Тодоровић, М., \& Бјељац, Ж. (2009). Rural tourism in Serbia as a concept of development in undeveloped regions, Acta geographica Slovenica, 49-2, 453-473.

22. Tourist Organization of Ivanjica: https://ivatourism.org/sr/ (May 25, 2019).

23. Vujić, M., Đorđević, S., Lakićević, M. (2019). Service quality and customer satisfaction in the hotel industry in Serbia, Hotel and Tourism Management, 7 (1), 61-70. doi:10.5937/menhottur1901061V 